\title{
Koncepcja bioregionalizmu w ekologii głębokiej
}

\author{
Widze sad nasz w kroplach błękitnych. \\ Cicho sierpien przywart do plotu \\ I w zielonych lapach swych lipy \\ Dzierża głośne ptasie szczebioty
} (S. Jesienin, Liryki najpiękniejsze)

Człowiek współczesny żyje w środowisku coraz bardziej nienaturalnym, które niejednokrotnie zostało przeobrażone w stopniu uniemożliwiającym korzystanie z jego walorów. Nic dziwnego, że nad wieloma obszarami naszej planety zawisła groźba katastrofy ekologicznej. Odsuwanie od siebie myśli o zagrożeniu, nie zmniejsza jego skali. Istotne jest przedsięwzięcie kroków zaradczych, mających na celu poprawę stanu środowiska oraz edukację, bez której wszelkie przedsięwzięcia przyniosłyby jedynie skutki chwilowe, o znikomym efekcie. Zwolennicy ekologii głębokiej (ekozofii) mają ambicje przemiany ludzkiej świadomości, a co za tym idzie kulturowego paradygmatu rozwoju ludzkości. Proponują alternatywną wizję wspólnoty międzyludzkiej, która wyraża się w idei bioregionalizmu. Koncepcja ta jest postulatem skierowanym do wszystkich ludzi, dlatego warto ją nieco dokładniej omówić. Pragnę więc w prezentowanym artykule dokonać krytycznej analizy idei zawartych w ekologii głębokiej jako niemożliwych do zrealizowania w obecnych uwarunkowaniach światowych.

Termin „ekologia głęboka” pojawił się po raz pierwszy na wykładzie, norweskiego filozofa Arne Naessa w 1872 roku, podczas konferencji w Bukareszcie. „Koncepcja ta stoi w opozycji do tradycyjnej ekologii opartej na antropocentrycznych postawach, którą Naess nazywa «ekologią płytką». Wini ją za bierną akceptację kryzysu ekologicznego, jakiego doświadcza współczesny świat, gdyż skoncentrowana jest wyłącznie na gromadzeniu informacji i ich systematyce. Bierność tradycyjnej ekologii jest przyczyną pogrążenia się świata w kryzysie ekologicznym. Przeciwieństwem jej jest «ekologia głęboka», która na porządku dziennym stawia pytania o aksjologiczne i światopoglądowe uwarunkowania istniejącego stanu rzeczy”. Określenie "głęboka” „odnosi się w części także do po-

\footnotetext{
S. Konstańczak, Wybrane zagadnienia ekofilozofii, Słupsk 2005, s. 104-105.
} 
ziomu pytań o nasze cele i przywoływane w konfliktach dotyczących korzystania ze środowiska naturalnego wartości”2. Aby skutecznie chronić środowisko nie wystarczy, bowiem sama świadomość istnienia zagrożeń, najistotniejszym czynnikiem jest odpowiedzialność za stan całego świata, który jest wspólnym dobrem wszystkich ludzi.

Obrońcy praw przyrody wywodzący się z tego nurtu uważają, że priorytetową sprawą jest rozbudzenie świadomości ekologicznej. Świadomość ta według nich nie jest niczym nowym dla człowieka, ponieważ wszystkie kultury pierwotne ją posiadały w formie poczucia tożsamości z naturą. Dobrym tego przykładem są, ich zdaniem, rdzenni mieszkańcy Ameryki. Dla Indian otaczający świat był jedną, wielką jednością, łańcuchem powiązań pomiędzy ludźmi, zwierzętami oraz roślinami. W Ekologii głębokiej, sztandarowym dziele tego nurtu można przeczytać „Istnieje współzależność między kształtowaniem świadomości ekologicznej a kształtowaniem sumienia. Historyk kultury Theodore Roszak w Person/Planet stwierdza: „Sumienie i świadomość, jakże zdumiewające jest podobieństwo tych dwu słów [w języku angielskim słowo conscience oznacza sumienie, a consciousness - świadomość. Z tej nowej świadomości, którą zyskujemy wzajemnie od siebie jako ludzie, uda nam się być może stworzyć jeszcze jakąś nową formę sumienia, taką, której wrażliwość etyczna nastrojona byłaby na wielkie dobro, wielkie zło"3. Chodzi tu oczywiście o wrażliwe reagowanie na problemy ze stanem środowiska, a nie obojętne nie robienie niczego, jakby nas bezpośrednio to nie dotyczyło.

Ciekawym i znaczącym elementem przy odnawianiu więzi z naturą są obrzędy, praktykowane w Zgromadzeniach Wszystkich Istot. Grupa tak składa się z kilku czy też kilkunastu osób. Podczas pobytu na, najlepiej na świeżym powietrzu, prowadzi się warsztaty opowiadania historii ewolucji czy też identyfikację $\mathrm{z}$ inną istotą, poprzez założenie wcześniej wykonanej maski oraz przemawianie $\mathrm{w}$ imieniu wybrane istoty np. niedźwiedzia czy sosny o tym, co ludzie uczynili z jego życiem ${ }^{4}$. Na pierwszy rzut oka może wydać się to trochę niepoważne, a nawet infantylne, jednak po głębszym zastanowieniu dojść można do wniosku, że jest w tym sens. Wszystkie kultury u zarania swych dziejów posiadały obrzędy i rytuały, które pozwalały na oczyszczenie. Wystarczy wspomnieć greckie dionizje czy misteria. U Jana Parandowskiego można przeczytać taki ich opis. „Kobiety z zapalonymi pochodniami, wśród śpiewów, biegały po wąwozach gór-

2 Filozofia i wychowanie, pod red. M. Foty, S. Konstańczaka, (Dariusz Liszewski Wkład ekologii glębokiej w ksztaltowanie modelu człowieka ekologicznego ), Materiały z I międzynarodowej konferencji naukowej zorganizowanej przez Instytut Filozofii WSP w Stupsku 25-26. 11. 1999, Słupsk 2000, s. 119.

3 B. DevalL, G. Sessions, Ekologia głęcoka Żyć w przekonaniu, iż Natura coś znaczy, Warszawa 1995, s. 24.

4 Zob. J. Seed, J. Macy, P. Fleming, A. Naess, Myślac jak góra, Warszawa 1992. 
skich. Obrzędy te nazywano orgiami, od słowa greckiego orge - podniecenie. Szalone tańce, dzikie okrzyki i ogłuszająca muzyka, wytwarzały ekstazę, zapamiętanie religijne, uważane za duchowe połączenie się z bóstwem. Zdawało się ludziom biorącym udział w tych świętych orgiach, że dusze ich opuszczają ciało, że sam bóg w nie wchodzi, że stają się "pełni boga». To poczucie odrębności ciała i ducha prowadziło do wiary w nieśmiertelność duszy, która jest cząstką człowieka niezniszczalną i po śmierci ciała przechodzi w nowe kształty"s. Analogicznie pośród warsztatów dotyczących ponownego odczucia więzi z naturą, dojść może do głębokich przeżyć wewnętrznych, które transformują osobowość, dają poczucie wewnętrznej siły. Być może współczesna cywilizacja, która zapomniała już niemal o tych dawnych tradycjach, potrzebuje nowych misteriów do wyrwania się z objęć rutyny i szarości. W głębi duszy każdy z nas ma w sobie coś z dzikusa, który z euforią mógłby tańczyć wokół ogniska, a jedynie gorset cywilizacyjny powstrzymuje nas od działań tego typu. Współczesny człowiek takiego oczyszczenia doznaje na koncercie lub w trakcie igrzysk sportowych. To jest obrzęd zastępczy. Przeżycia te, pomimo że silne, nie powodują (a przynajmniej rzadko) poczucia jedności z naturą, które było tak istotne dla ludów pierwotnych. Na podobnej zasadzie działają praktyki religijne. Zasada jest jedna, człowiek potrzebuje przeżyć emocjonalno-duchowych do prawidłowego funkcjonowania, do odnalezienia własnego poczucia tożsamości ze światem.

Ekologia głęboka bazując na tej odwiecznej potrzebie, chce przywrócić człowiekowi możliwość kontaktu emocjonalnego ze wszystkim, co go otacza. Uważam, że jest to jeden z mocniejszych punktów ekologii głębokiej. Uderzający natomiast w niej, jest antyantropocentrym, ponieważ według zwolenników tej koncepcji, wszelkie formy życia mają takie same prawa do przetrwania. Nie mogę się zgodzić do końca z tym poglądem, ponieważ prawo natury jest prawem silniejszego albo sprytniejszego. Nie można wymagać od drapieżnika, aby stał się nagle łagodną sarenką, bo to niedorzeczne. Człowiek dzięki ogromnemu rozwojowi umysłu stoi przecież wyraźnie na pozycji uprzywilejowanej. Każde stworzenie dąży do zaspokojenia swoich potrzeb, do spotęgowania własnych możliwości przetrwania. Wilk nie zastanawia się nad losem zająca, ani nad tym czy wpłynie znacząco na jego populację, a zapewne nawet gdyby ją wytępił to znalazłby zaraz inny obiekt polowań. Zając, aby przetrwać musi licznie się rozmnażać. Tyle tylko, że człowiek bardzo często zabija nie po to, aby przeżyć. Jednak bezspornie człowiek zaopatrzony w nowoczesną broń, jest myśliwym doskonałym i często nadużywa swojej przewagi nad resztą stworzeń.

Dla zwolenników ekologii głębokiej bardzo istotna jest wspólnota. Naturalnym sposobem organizowania się właśnie w wspólnotę miałby być bioregion "cechą bioregionu jest samoregulacja. Jak twierdzi Dodge, „anarchia

J. Parandowski, Mitologia wierzenia i podania Greków i Rzymian, Warszawa 1978, s. 126-127. 
nie oznacza braku kontroli; oznacza jedynie brak kontroli z zewnątrz"' ${ }^{\text {". Jest to }}$ oczywiście postulat decentralizacji władzy. Kontrowersyjny z uwagi na rzeczywistość, w jakiej wszyscy żyjemy. Ekozofowie twierdzą, że ludy prymitywne żyły $\mathrm{w}$ wspólnotach alternatywnych, gdzie wódz był przede wszystkim przewodnikiem, nie władcą. „Po pierwsze, pragniemy zachęcić agencje, ustawodawców, właścicieli ziemi oraz menadżerów, aby spróbowali zestroić się z procesami naturalnymi, zamiast je wymuszać. Po drugie, w praktyce faworyzujemy pracę w ramach tradycji alternatywnej, we wspólnocie lokalnej, a zwłaszcza w bioregionie" . Wiązałoby się to wszystko $\mathrm{z}$ samodzielnym wytwarzaniem energii czy żywności na własny użytek. Podstawowymi cechami wspólnoty miały by być: autonomia lokalna, pomaganie innym, komunikowanie się z naturą. Wspólnota taka miałaby podlegać własnej regulacji, bez angażowania się sił z zewnątrz, np. wojska czy policji. Ekozofowie twierdzą jednak, ze „Tradycja ta, według naszych kryteriów, nie oznacza też braku kontroli nad poszczególnymi ludźmi ani braku jasnego myślenia"s. To dość utopijna wizja, ponieważ chęć dominacji, posiadania dóbr materialnych, oraz czerpania przyjemności jest w ludziach dużo silniejsza niż zdolność do wyrzeczeń czy też rezygnacji z dobrobytu i bezpieczeństwa (czasem nawet ułudy bezpieczeństwa), jakie daje władza oraz hierarchiczny jej układ. Rzeczą niemożliwą jest, aby współczesny człowiek zrezygnował z najnowszych maszyn, usług, samochodów, biotechnologii, badań genetycznych, urbanizacji. Natomiast możliwe będzie autentyczne skupienie się na ochronie przyrody, zamiana wszystkich paliwa na ekologiczne, wytworzenie materiałów zastępczych, aby mniej eksploatować lasy oraz źródła surowców energetycznych, recykling. Nie można jednak mieć pretensji do ludzi, że tworzą swoją specyficzną antroposferę, zwierzęta, gdyby były świadome w taki sposób jak człowiek, tworzyłyby także własną i miałyby równie ekspansywny stosunek do rzeczywistości. Nie należy ulegać fascynacji „dobrą naturą", w której wszelkie procesy odbywają się bez przemocy. Jest to absurd, natura nie jest ani dobra, ani zła, podobnie jak samo życie. Ona po prostu jest, rządzi się prawami ewolucji i dążności do przetrwania. Centralizacja władzy w kraju jest właśnie metodą przetrwania całego państwa i nie można żyć złudzeniami, że utworzenie anarchistycznych komun, o pacyfistycznym nastawieniu wyjdzie człowiekowi w obecnych uwarunkowaniach na dobre. Ze względów mentalnych jest to niemożliwe, całe pokolenie należałoby wychować w zupełnie inny sposób, aby coś takiego mogło być realne. Jednak bardzo różnimy się w odczytywaniu rzeczywistości od np. Indian przedkolumbijskich. Natomiast tworzenie grup proekologicznych, fundacji, ośrodków pro-

B. Devalt, G. Sessions, Ekologia głęboka Żyć w przekonaniu, iż Natura coś znaczy, Warszawa 1995 , s. 41.

7 Tamże, s. 190.

8 Tamże, s. 37-38. 
pagowania ochrony środowiska jest jak najbardziej pożądane i realne. Dobrym tego przykładem są państwa skandynawskie, rozsądne polityka proekologiczna powoduje to, ze np. w Finlandii można zaczerpnąć wody wprost $\mathrm{z}$ jeziora, ponieważ jest ono czyste, albo w Szwecji posiadanie roweru jest swoistym symbolem ekologicznym, mimo że na samochód stać prawie każdego.

Według Ignacego Fiuta poglądy głoszone przez Naessa jako antyantropocentryzm „są jednak antropocentryczne, gdyż mają na uwadze w ostatniej instancji pomyślność naszego gatunku”. Wydaje mi się to rzeczą bardzo naturalną, że ostatecznie chodzi pomyślność naszego gatunku, a nie jego zniszczenie. To oczywiste, antyantropocentryzm jest postulatem ekologii głębokiej, mimo, że ukryty jest w nim bezwiedny antropocentryzm. Natomiast w sposób świadomy kierunek ten jest nastawiony na biocentryzm, czyli nie faworyzowanie jakiegokolwiek gatunku, w domyśle oczywiście chodzi o ludzki. „Zdaniem autorów z kręgu głębokiej ekologii niezwykle istotne jest urzeczywistnienie równości ekologicznej. Wszystkie gatunki roślin i zwierząt są sobie równe. Interes każdego $\mathrm{z}$ nich jest poprzedzony interesem całości” ${ }^{\prime 10}$. To bardzo szlachetna propozycja, jednak niezgodna z mentalnością większości współczesnych ludzi, jedynie pewna grupa osób mogłaby w sposób naprawdę świadomy przyjąć biocentryzm na serio. Ludziom trudno jest uznać równość między sobą (rasizm, ksenofobia, homofobia, szowinizm, nacjonalizm, nietolerancja religijna), a cóż dopiero uznać, że są na równi ze zwierzętami i roślinami. Zresztą nie bez podstaw rodzaj ludzki uważa się za koronę ewolucji, doskonalszej formy od nas natura nie wytworzyła. Nie oznacza to oczywiście, że daje nam to prawo do bezkarnej eksploatacji Ziemi czy bezmyślnego dewastowania środowiska. Za realne jednak uznać trzeba, że dla ludzi przetrwanie i wygoda są w gruncie rzeczy miarą ostateczną. Jakkolwiek postulaty ekologii głębokiej mają wiele słuszności, to ich "głębia” sięga utopii, przynajmniej w obecnym XXI wieku. Z pewnością edukacja ekologiczna ma ogromne znaczenie i powinna stanowić istotny element w edukacji w ogólnym pojęciu. Bardzo słusznie zauważa Arne Naess, że tradycyjne wykształcenie, nie spełnia w sposób właściwy swojej roli. Jako przykład przytoczę tu wypowiedź „praca, na przykład ze studentami biologii, dostarcza zupełnie innych, smutnych doświadczeń. Kiedy przebywałem z takimi ludźmi w przepięknym krajobrazie dolnej Kaliforni doświadczyłem, że całe lata spędzili oni na nadawaniu nazw. A kiedy już posiedli te nazwy, zaczynali mówić, mówić i mówić. Kiedy więc pracowaliśmy razem zaproponowałem im godzinę

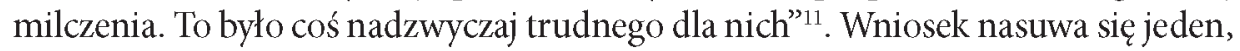

9 I. S. FIUT, Ekoetyki Kierunki rozwoju aksjologii wspótczesnej przyjaznej środowisku, Kraków 1999 , s. 60 .

${ }^{10}$ Interdyscyplinarne podstawy ochrony środowiska przyrodniczego, praca zbiorowa pod kierunkiem B. Prandeckiej, Wrocław-Warszawa-Kraków 1993, s. 48.

11 A. NAEss, Rozmowy Zeszyt edukacji ekologicznej „PRACOWNI NA RZECZ WSZYSTKICH ISTOT" zeszyt 2-lato 1992, s. 5-6. 
wykształcenie biologiczne nie uczy żadnej wrażliwości ani otwartości na kontakt z naturą. "Wykucie” choćby tysiąca łacińskich nazw nie przybliża ani o krok do poczucia jedności z otaczającą przyrodą. Człowiek ekologiczny, postulowany przez ekozofów miałby stanowić element przełamujący obraz wykształconego, choć niekoniecznie mądrego biologa.

Zwolennicy ekologii alarmują i pouczają, że przede wszystkim należy sobie zdać z tego sprawę, że każda ingerencja w jakikolwiek ekosystem nie jest dla niego czymś obojętnym. Jako dobry przykład można przedstawić zapory budowane na rzekach. „Zapory, szczególnie całe ich serie, burzą to, co jest główną, naturalną cechą rzek, ich ciągłość od źródeł aż po ujście. [...] Obecność przegród zmienia ilość wody i siłę jej prądu w sposób dający się odczuć nawet w odległych partiach rzeki. Seria następujących po sobie wielkich tam kompletnie burzy naturalny, sezonowy rytm przepływu"12. Ekozofowie z nurtu głębokiego potrafią w takich sytuacjach, kiedy istnieje zagrożenie ekosystemu wodnego zburzyć, lub uszkodzić tamę. Są to oczywiście z punktu widzenia prawa działania nielegalne, wiążące się interwencjami policji itp. Jednakże z punktu widzenia dobra populacji bytujących w rzece działania te są dobre. Tak jak pozwoliłam sobie zauważyć wcześniej, ludzkie wygodnictwo i chęć czerpania zysków stają się miarą ostateczną. Przecież mało kto ubolewa nad naruszeniem biorównowagi w cieku wodnym, natomiast bardzo silnie uwypuklane są straty materialne jakie poniósł inwestor budujący zaporę.

„W modelu industrialnym celem rozwoju jest maksymalizacja wzrostu gospodarczego opartego na ekspansywnej eksploatacji zasobów naturalnych i ludzkich (human resources), działalność dużych, wyspecjalizowanych zakładów i instytucji o wyraźnie określonych kompetencjach i zakresach działania, parametrycznej ocenie efektywności, utylitarno-funkcjonalne pojmowanie nauki, zdrowia, edukacji. [...] W modelu ekologicznym celem rozwoju jest aktualizowanie możliwie wszystkich potencjalnych wartości społecznych i indywidualnych w możliwej równowadze ze środowiskiem przyrodniczym i równie nie ujednostronnionych relacjach ze środowiskiem społecznym i psychologicznym. Ich zasoby są nie tyle przeliczane, ile precyzyjnie rozpoznawane w celu intensyfikacji ich jakości"13. Robiąc podobne zestawienie koncepcji modelu życia, nasuwa się myśl o tym, iż należałoby zmienić paradygmat kulturowy, na rzecz nowego. To właśnie sugerują zwolennicy ekologii głębokiej, chodzi im o walkę z zamkniętą strukturą, myślenia jedynie o eksploatacji, nie licząc się z konsekwencjami takiego postępowania. Jako swoisty imperatyw naczelny wysuwają w związku z tym postulat poszanowania istot pozaludzkich.

12 J. D. Allan, Ekologia wód plynących, Warszawa 1998, s. 355.

13 J. B. Faliński, A. Kalinowska, L. Korporowicz, F. Plit, Podstawy ochrony środowiska 1, Warszawa 1993, s. 62. 
Podsumowując: koncepcja bioregionalizmu w ekologii głębokiej to koncepcja wspólnoty wszystkich istot, ludzkich, zwierzęcych oraz roślinnych. To propozycja alternatywnego sposobu funkcjonowania, w stosunku do jego tradycyjnej wersji. Szczególną troską otoczone zostają w niej wszelkie przejawy natury, którą traktuje się jak coś nieodłącznego człowiekowi. Wzorcami dla takiego modelu są tradycje ludów pierwotnych, które potrafiły w współ funkcjonować z środowiskiem przyrodniczym, nie narażając go jednocześnie na dewastację ani spustoszenie ekosystemów w nim bytujących. Granica pomiędzy człowiekiem, a naturą nie była wówczas postrzegana w tak ostry sposób jak współcześnie. Bioregion miałby stanowić miejsce przyjazne zarówno dla ludzi jak i innych stworzeń. Z pewnością postulat ten, jest oparty o rozwój gospodarki lokalnej. Najważniejszymi punktami takiej gospodarki są kapitał ludzki, społeczny, bogactwo naturalne. „Podniesienie wartości wytworów lokalnych można uzyskać poprzez uświadomienie konsumentom, że mają do czynienia $z$ towarami wiadomego pochodzenia oraz, że jest to towar wyjątkowy - lepszy od innych"14. W koncepcji takiej zawsze przodują producenci „zdrowej” żywności, nie nastawieni na masową, wielotysięczną sprzedaż. To oczywiście wpływa zarówno na zdrowie konsumentów jak i na wysoką jakość nabywanego towaru. Agro-turystyka czy też eko-turystyka to kolejny mocny punkt gospodarki lokalnej, stwarza, bowiem nowe miejsca pracy, poprawia popyt na miejscowe atrakcje oraz produkty. „Gospodarstwa ekologiczne z reguły zatrudniają więcej pracowników niż gospodarstwa tradycyjne”15. Uważam, że koncepcja bioregionu, powinna być w sposób silny nastawiona na tego typu działalność, ponieważ może to stanowić motor rozwoju ekonomicznego całego regionu. Wszystko to powinno być jeszcze wsparte na wykorzystywaniu odnawialnych źródeł energii (wiatr, zwierzęce odchody), dlatego, że wytwarza się przy tym niewielkie ilości odpadów, co oczywiście w sposób korzystny wpływa na środowisko: „energia produkowana przez wiatr i użytkowana na miejscu jest tańsza niż czerpana z sieci, nie wymaga też wysokich nakładów zewnętrznych. W 1998 roku w wielkiej Brytanii obiekty tego typu zatrudniały 2200 osób, wytwarzając energię zdolną zaspokoić potrzeby 125 tys. gospodarstw domowych"16. Przytoczony fragment stanowi dobry przykład na rozumne i ekologiczne rozwiązania. Aby na poziomie lokalnym można było w sposób rozsądny i efektywny doprowadzić do zrównoważonego funkcjonowania, należałoby zmienić politykę podatkową. „Reformie podatkowej powinny towarzyszyć przepisy wymuszające stosowanie pro ekologicznych technologii, zmiany strukturalne w poszczególnych sektorach gospodarki, integrowanie różnych sektorów, a w szczególności przepisy zmieniające politykę wobec ośrodków rolniczych oraz drobnych przedsiębiorstw lokalnych i instytucji zajmujących się ochroną przyrody"17.

14 J. Pretty, O rozwoju gospodarki lokalnej, Warszawa 2000, s. 22.

15 Tamże, s. 20.

16 Tamże, s. 24.

17 Tamże, s. 28. 
Przyglądając się z uwagą koncepcji bioregionu można odnieść wrażenie, że bioregionalna gospodarka musiałaby mieć charakter autarkii, ponieważ, aby nie ingerować $\mathrm{w}$ przyrodę należałoby powstrzymać rozbudowę autostrad, lotnisk oraz portów. Rzeczą naprawdę trudną jest wyobrażenie sobie takiego stanu, w którym potencjalny klient miałby zrezygnować z produktów przywożonych z odległych regionów (np. oliwek, krewetek, pomarańczy) na rzecz tylko takich, które akurat występują w danym regionie. Wydaje mi się, że to ważny argument, który może zostać wytoczony przez przeciwników a nawet umiarkowanych entuzjastów bioregionalizmu. Jest to bowiem, z punktu widzenia konsumenta, duże ograniczenie jego swobody wyboru.

O ile mamy do czynienia z utopijną koncepcją, o tyle zwolennicy ekologii głębokiej nie uważają, aby przez to byłą czymś mniej wartościowym, od realniejszych projektów. „Wielką niesprawiedliwością byłoby odrzucenie myśli utopijnej jako nie znajdującej potwierdzenia w praktyce, wizjonerskiej i będącej czystą fantazją; utożsamienie jej jedynie $\mathrm{z}$ formami literackimi, które się na nią powołują, jest równoznaczne $\mathrm{z}$ niedocenieniem ogromnej popularności, jaką cieszy się $\mathrm{w}$ wielu dziedzinach $i$ we wszystkich kulturach. Bez względu na formę jej wyrazu w swojej istocie jest ona krytyką niedoskonałości i ograniczeń tkwiących w społeczeństwie, lecz również wyraża tęsknotę za czymś lepszym"18. Wyraźnie dostrzec można w przytoczonym fragmencie ogromne zaangażowanie, jakim odznaczają się ekologia głęboka, nawet rzec można by żarliwością. Niestety smutnym faktem jest to, że propozycje ekozofów, pomimo, że szlachetne we współczesnym świecie są niemal niemożliwe do zrealizowania. Składa się na to szereg bardzo różnych uwarunkowań, których wspólną cechą jest skuteczne blokowanie działań proekologicznych. Uważam, jednak, że pomimo złych prognoz dotyczących stanu środowiska bardzo istotną sprawa jest edukacja. „Świadomość kryzysu ekologicznego w istotny sposób ograniczyła nasz optymizm i skłania zbyt często do formowania wizji katastroficznych"19. Przyszłe pokolenia należy wychować i wyedukować w sposób pozytywny. Bierność, brak zaangażowania oraz negatywny obraz czekającej ludzkość przyszłości nie wpływają w żadnej mierze budująco. Obecny wiek, bowiem może stanowić przedsionek do wieku rozwagi oraz społeczeństwa ekologicznego. Przyszłość zależy od nas wszystkich, co prawda nie w równym stopniu, ale zaczynając od własnych domów i podwórek, możemy przyczynić się do kształtowania odpowiednich postaw, oraz polepszenia stanu środowiska. Ekologia głęboka i zawarte w niej postulaty nie są jeszcze możliwe do zrealizowania, jednakże przyszłe pokolenia mogą je uczynić rzeczywistymi w dużym stopniu. Wątpię, aby udało się spełnić ta wizje w całości, ponieważ ludzkość nie jest dostatecznie mądra i wrażliwa, ale wierzę, $\mathrm{w}$ to, że realizacja wielu zagadnień jest możliwa w najbliższych stuleciach.

18 B. Devald, G. Sessions, Ekologia gtęboka Żyć w przekonaniu, iż Natura coś znaczy, Warszawa 1995, s. 211.

19 S. Konstańczak, Wybrane zagadnienia ekofilozofii, Słupsk 2005, s. 192. 


\section{Literatura}

1. Allan J. David, Ekologia wód plynacych, Warszawa 1998.

2. Davall Bill, Sesisons George, Ekologia glęboka Żyć w przekonaniu, iż natura coś znaczy, Warszawa 1995.

3. Faliński Janusz B., Kalinowska Anna, Korporowicz Leszek, Pilt Florian, Podstawy ochrony środowiska, t. 1, Warszawa 1995.

4. Filozofia i wychowanie Materialy z I międzynarodowej konferencji naukowej zorganizowanej przez Instytut Filozofii WSP w Słupsku 25-26. 11. 1999, pod red. Foty Marka, Konstańczaka Stefana, Słupsk 2000.

5. Fiut Ignacy Stanisław, Ekoetyki Kierunki rozwoju aksjologii współczesnej przyjaznej środowisku, Kraków 1999.

6. Fleming Pat, Naess Arne, Seed John, Macy Joanna, Myśląc jak góra, Warszawa 1992.

7. Interdyscyplinarne podstawy ochrony środowiska przyrodniczego, praca zbiorowa pod kierunkiem B. Prandeckiej, Wrocław-Warszawa-Kraków 1993.

8. Jesienin Sergiusz, Liryki najpiękniejsze, Torun 2000.

9. Konstańczak Stefan, Wybrane zagadnienia ekofilozofii, Słupsk 2005.

10. Naess Arne, Rozmowy Zeszyt edukacji ekologicznej, Pracownia na rzecz Wszystkich Istot, zeszyt 2 - lato 1992

11.Parandowski Jan, Mitologia wierzenia i podania Greków i Rzymian, Warszawa 1978.

12.Pretty Jules, O rozwoju gospodarki lokalnej, Warszawa 2000.

\section{The Concept of Bio-regions in Advanced Ecology}

\section{SUMMARY}

The article analyses the notion of the eivironment, showing the concept of bio-regions and presenting the main principles of advanced Ecology. In addition, it explores bio-regions in the light of advanced Biology. 